\title{
BTAF1 wt Allele
}

National Cancer Institute

\section{Source}

National Cancer Institute. BTAF1 wt Allele. NCI Thesaurus. Code C52513.

Human BTAF1 wild-type allele is located within 10q22-q23 and is approximately $106 \mathrm{~kb}$ in length. This allele, which encodes TATA-binding protein-associated factor 172 protein, plays a role in the initiation of RNA polymerization. 